\title{
Chemical composition, antioxidant and biological activity of Ocotea bicolor Vattimo-Gil (LAURACEAE) essential oil
}

\author{
Carolina Sette Barbosa Damasceno ${ }^{1 *}$, Letícia Freire de Oliveira ${ }^{2}$, Ellis Marina Szabo' ${ }^{1}$, Ângela \\ Maria Souza $^{2}$, Josiane Fatima Gaspari Dias², Marilis Dalarmi Miguel², Obdúlio Gomes Miguel ${ }^{1}$
}

\begin{abstract}
${ }^{1}$ Laboratório de Fitoquímica, Departamento de Farmácia, Universidade Federal do Paraná, Curitiba, Brasil, ${ }^{2}$ Laboratório de Farmacotécnica, Departamento de Farmácia, Universidade Federal do Paraná, Curitiba, Brasil
\end{abstract}

\begin{abstract}
The essential oil composition of the Ocotea bicolor, native plant of Brazil, was studied for the first time. The essential oil of the leaf was obtained by hydrodistillation and analyzed by GC/MS. The analytical procedure revealed a predominance of sesquiterpenes, $\delta$-cadinene $(7.39 \%), \beta$-sesquiphellandrene (6.67\%), $\beta$-elemene $(5.41 \%)$ and $\alpha$-cadinol $(5,23 \%)$. The essential oil was submitted to brine shrimp toxicity evaluation, antioxidant and antibacterial tests. The antioxidant activity by the formation of phosphomolybdenum complex method presented positive results. The minimum inhibitory concentration (MIC) values were higher than $1000 \mu \mathrm{g} / \mathrm{mL}$ for the microorganisms tested. Toxicity activity revealed LC50 results of $40.10(\mu \mathrm{g} / \mathrm{mL})$, being toxic to the organisms in this study.
\end{abstract}

Keywords: Ocotea bicolor/Oil essential/chemical composition. Lauraceae. Antioxidant activity. Biological activity.

\section{INTRODUCTION}

The Lauraceae family is composed of approximately 2.750 species, distributed in 54 genera. It is prevalent in tropical regions of America and Asia, along with having a large number of species in Australia and Madagascar, with an insignificant number of species in Africa. The species are predominantly trees and mostly aromatic in nature (Van Der Werff, Ritcher, 1996; Madriñán, 2004).

Ocotea bicolor Vattimo-Gil, native to Brazil is locally known as cinnamon-shit or cinnamon-stinking, justified by the unpleasant odour from their wood (Brotto, Cervi, Santos, 2013). The studies on this species are still incipients, with no information about their chemical characteristics. However, many chemical investigations were carried out for other Ocotea species, reporting benzylisoquinoline alkaloids (Takaku, Haber, Setzer, 2007), lignans and neolignans (Silva, BrazFilho, Gottlieb, 1989) and essential oils composed of monoterpenes, sesquiterpenes and phenylpropanoids (Bruni et al., 2004).

\footnotetext{
*Correspondence: C. S. B. Damasceno. Laboratório de Fitoquímica, Departamento de Farmácia, Universidade Federal do Paraná, Curitiba, Brasil. Phone: +55 41 33604070. E-mail: carolsete@hotmail.com
}

The Ocotea genus is the most studied in the Lauraceae family, was characterized mainly by the presence of antimicrobial, antifungal (Bruni et al., 2004) and anti-inflammatory activity (Chao et al., 2005). In this study, the unpublished description of the chemical composition, the evaluation of the antioxidant, bactericidal and toxic potential of the essential oil of Ocotea bicolor Vattimo-Gil leaves are carried out.

\section{MATERIAL AND METHODS}

\section{Plant material}

The botanical material collection was carried out in the Capão do CIFLOMA region at the Botanical Campus of the Federal University of Paraná, Curitiba, Paraná state, Brazil, in August, 2015. All the plant material was obtained from the same specimen, in a sterile phase. Witness material was identified by the taxonomist Marcelo Leandro Brotto, and deposited in Herbarium of the Department of Botany of the Federal University of Paraná, under registry $n^{\circ} 88118$.

This study has been authorized by the Brazilian Institute of the Environment (IBAMA) to access samples of the genetic patrimony for scientific research purposes 
without potential economic use, included in Process 02001.001165 / 2013-47.

\section{Essential oil obtaining}

The essential oil was obtained from $100 \mathrm{~g}$ of dried leaves, ground in a knife mil, hydrodistilled for 6 hours using modified Clevenger type apparatus. The essential oil was stored in a sealed amber glass at $-18{ }^{\circ} \mathrm{C}$ until the analysis. The yield calculation was performed in milliliters $(\mathrm{mL} / \%)$ of essential oil per $100 \mathrm{~g}$ of the drug (Farmacopeia Brasileira, 2010).

\section{Identification of essential oil constituents}

The characterization of the chemical constituents present in the essential oil of the Ocotea bicolor VattimoGil leaves was carried out at the laboratory of the Chemistry, Department of the Federal University of Paraná, using gas chromatography, composed of a gas chromatograph coupled to a spectrometer Shimadzu ${ }^{\circledR}$ CGEM-QP 2010 Plus mass equipped with Rtx-5MS capillary column (30 mx $0.25 \mathrm{~mm}$ x $0.25 \mu \mathrm{m})$. Injector in splitless mode at $250{ }^{\circ} \mathrm{C}$, interface and source of ions at $300{ }^{\circ} \mathrm{C}$. The mass window analyzed was between $\mathrm{m} / \mathrm{z} 40$ and $\mathrm{m} / \mathrm{z}$ 350 , using He as drag gas. Injection ramp for analysis with injector temperature at $250^{\circ} \mathrm{C}$, column pressure of $20 \mathrm{psi}$, starting with a temperature of $50^{\circ} \mathrm{C}$ for 5 minutes rising to $200^{\circ} \mathrm{C}$ at a rate of $5^{\circ} \mathrm{C} / \mathrm{min}$. The chemical components of the oil were identified comparing their mass spectra with the reference spectra, and comparing their Kovat indices with those described in the literature (Adams, 2007).

\section{DPPH}

The sequestering potential of Radical DPPH (2,2-diphenyl-1-picrylhydrazyl) was determined using ascorbic acid and rutin as standard, by adapted technique (Mensor et al., 2001; Santos et al., 2007; Nascimento et al., 2011). Methanolic solutions of the sample were prepared from a stock solution $(1 \mathrm{mg} / \mathrm{mL})$ at concentrations ranging from $2 \mu / \mathrm{mL}$ to $500 \mu \mathrm{g} / \mathrm{mL}$. 96-well microplates with round bottoms were used, with $71 \mu \mathrm{L}$ of the sample and $29 \mu \mathrm{L}$ of the DPPH solution $(0.3 \mathrm{mM})$. The specific blank of each sample was determined using $71 \mu \mathrm{L}$ of the sample and $29 \mu \mathrm{L}$ of methanol, and the negative control $71 \mu \mathrm{L}$ of methanol and $29 \mu \mathrm{L}$ of DPPH.

Absorbance readings were taken after thirty minutes of incubation under light in the Multiskan FC spectrophotometer, Thermo Scientific $\AA$ at wavelength 518 $\mathrm{nm}$. The percentage of inhibition was obtained through the equation: \% Inhibition $=100$ - [(Absorbance of sample white absorbance)/absorbance of standard] X 100. From the percentages of inhibition of DPPH, by linear regression the IC50 was calculated, that is, the concentration required to exert $50 \%$ of the antioxidant activity. The IC50 results were compared according to Tukey's statistical method $(p<0.05)$.

\section{Formation of the Phosphomolybdenum Complex method}

The antioxidant activity through the phosphomolybdenum complex reduction method was performed using the standard solutions of ascorbic acid and rutin, that were prepared at the concentration of $200 \mu \mathrm{g}$ $/ \mathrm{mL}$ in methanol and $0.5 \%$ DMSO, as well as the samples (Prieto, Pineda, Aguilar, 1999). Aliquots of $0.3 \mathrm{~mL}$ were added to $3 \mathrm{~mL}$ of the phosphomolybdenum reagent $(0.1$ M tribasic sodium phosphate $(28 \mathrm{~mL}), 0.03 \mathrm{M}$ ammonium tetrahydrate molybdate solution $(12 \mathrm{~mL}), 3 \mathrm{M}$ sulfuric acid $(20 \mathrm{~mL})$ and water until complete $100 \mathrm{~mL})$. The tubes were closed and brought to the thermostated bath at $95^{\circ} \mathrm{C}$ for $90 \mathrm{~min}$. After cooling, the absorbances were obtained in 96-well microplates with round bottoms by reading in the Multiskan FC spectrophotometer, Thermo Scientific ${ }^{\circledR}$ at wavelength $695 \mathrm{~nm}$. The antioxidant capacity of the samples was expressed in relative antioxidant activity (AAR\%), in relation to the standards, using the equation: AAR $\%=[($ Sample Absorbance - Absorbance of White $) /$ (Absorbance of Standard - Absorbance of White)] X 100 The variance of the obtained results was evaluated by the ANOVA test and the difference between the means verified by the test ( $\mathrm{t})$ by Scott and Knott $(\mathrm{p}<0.05)$.

\section{Minimum inhibitory concentration (MIC)}

The antimicrobial activity was determined in vitro, with modifications from the original method, using the broth microdilution method to determine the minimum inhibitory concentration (MIC) (CLSI, 2012).

The sample was solubilized in $0.5 \%$ of Polysorbate 80 and tested in concentrations between 1000 and $7.8 \mu \mathrm{g}$ / $\mathrm{mL}$ with the following microorganisms: Escherichia coli (ATC 25922), Pseudomonas aeruginosa (ATCC 27853), Staphylococcus aureus (ATC 25923), Enterobacter aerogenes (ATCC 13048), Klebsiella pneumoniae (ATCC 700603), Staphylococcus epidermidis (ATCC 12228) and Salmonella typhimurium (ATCC 14028). The bacterial suspensions were prepared in saline solution at a concentration of $1.0 \times 108 \mathrm{CFU} / \mathrm{mL}$, which corresponds to the 0.5 scale of Mac Farland. $10 \mu$ Lof the bacterial strain was inoculated resulting in a final concentration of $104 \mathrm{CF}$ 
$/ \mathrm{mL}$. The negative control of the inhibitory activity of the diluents, ethanol and DMSO, were performed adding 100 $\mu \mathrm{L}$ of $10 \%$ ethanol solution and $2 \%$ DMSO in $100 \mu \mathrm{L}$ of $\mathrm{MHB}$ and $10 \mu \mathrm{L}$ of the bacterial inocula. For the sterility control, $100 \mu \mathrm{L}$ of MHB and $100 \mu \mathrm{L}$ of the extract and fraction were used. The positive control was prepared with $100 \mu \mathrm{L}$ of $\mathrm{MHB}$ and $5 \mu \mathrm{L}$ of the bacterial inocula. The microplates were closed and maintained in bacteriological oven at $35^{\circ} \mathrm{C}$ for a period of 16 to $20 \mathrm{~h}$. After incubation, was added $20 \mu 1$ of aqueous 2,3,5-triphenyltetrazolyl chloride (TTC) solution at $0.5 \%$, and the microplates were reincubated for $3 \mathrm{~h}$ at $35^{\circ} \mathrm{C}$. Then, the results reading was taken for the results. Wells with bacterial growth showed red coloration. The minimum inhibitory concentration was considered from the well with no color.

\section{Brine shrimp lethality assay}

The toxicity assay employs the larvae of the brine shrimp Artemia salina Leach was performed using a saline solution containing $30 \mathrm{~g} \mathrm{~L}^{-1}$ of sea salt (Meyer et al., 1982) prepared with $\mathrm{pH}$ adjustment to 9 with $\mathrm{Na}_{2} \mathrm{CO}_{3}$. This solution was used in the hatching of Artemia salina cysts and in the preparation of dilutions. The cysts were placed to hatch in the saline solution for 48 hours, under continuous aeration and exposure to daylight. The temperature was controlled between 27 and $30^{\circ} \mathrm{C}$ and the $\mathrm{pH}$ between $8-9$.
In the first hour of the process the recipient was kept under illumination $(20 \mathrm{~W})$. After hatching of the cysts, 10 larvae of Artemia salina were transferred to tubes containing saline solution and added with the following samples: Essential oil diluted in $0,5 \%$ of Polysorbate 80 and saline solution tested at concentrations of 10,100 and $1000 \mu \mathrm{g} / \mathrm{mL}$, followed by a positive control prepared with saline solution and sodium dodecylsulfate (SDS), and negative control with saline solution and Polysorbate 80 . Whole assay was performed in triplicate. The tubes were incubated in oven $\left(27-30^{\circ} \mathrm{C}\right)$ for 24 hours, for later counting of nauplii. The results were submitted to statistical treatment using the PROBIT method, which provided LC50 values (Lethal concentration to $50 \%$ of individuals) with $95 \%$ reliability. The degree of toxicity was classified as: low toxicity: LC50>500 $\mu \mathrm{g} / \mathrm{mL}$; moderate toxicity: LC50 between $100 \mu \mathrm{g} / \mathrm{mL}$ to $500 \mu \mathrm{g} / \mathrm{mL}$ and high toxicity: LC50<100 $\mu \mathrm{g} / \mathrm{mL}$ (Amarante et al., 2011).

\section{RESULTS AND DISCUSSION}

The analysis of the essential oil of $O$. bicolor leaves allowed the recognition of the sesquiterpenes predominance $(48.21 \%)$, followed by alcohols, ketones and aldehydes $(31.97 \%)$ and in lesser amount, aromatic sesquiterpenes $(0.56 \%)$ and diterpenes $(1.14 \%)$. It was possible to identify 38 constituents totaling $81.88 \%$, whose retention times, retention indices and percentages are summarized in Table I.

TABLE I - Chemical compounds present in the essential oil of Ocotea bicolor determined by CG / MS

\begin{tabular}{lllll}
\hline Compounds & TR & IRc & IRt & $(\mathbf{\% )}$ \\
\hline Sesquiterpenes & & & & 1.78 \\
$\alpha$-cubebene & 22.523 & 1354 & 1345 & 2.48 \\
$\alpha$-Ylangene & 23.696 & 1381 & 1373 & 0.92 \\
$\beta$-bourbonene & 24.100 & 1390 & 1387 & 5.41 \\
$\beta$-elemene & 24.425 & 1397 & 1389 & 2.86 \\
E- caryophyllene & 25.615 & 1426 & 1417 & 0.16 \\
$\beta$-copaene & 26.006 & 1435 & 1430 & 1.24 \\
Trans-muurola-3,5-diene & 26.921 & 1457 & 1451 & 2.90 \\
$\alpha$-humulene & 27.073 & 1460 & 1454 & 0.53 \\
Allo-aromadendrene & 27.380 & 1468 & 1458 & 0.78 \\
Dauca-5,8-diene & 27.901 & 1480 & 1471 & 2.21 \\
Germacrene D & 28.053 & 1484 & 1484 & 2.48 \\
$\alpha$-cubenene & 28.238 & 1488 & 1478 & 1.09 \\
Bicyclogermacrene & 28.902 & 1504 & 1500 & 1.92 \\
$\alpha$-murolene & 29.034 & 1507 & 1500 & 0.66 \\
E,E- $\alpha$-farnesene & 29.257 & 1513 & 1505 & 6.67 \\
$\beta$-sesquiphellandrene & 29.657 & 1523 & 1521 & \\
\hline
\end{tabular}


TABLE I - Chemical compounds present in the essential oil of Ocotea bicolor determined by CG / MS (cont.)

\begin{tabular}{|c|c|c|c|c|}
\hline Compounds & TR & IRc & IRt & $(\%)$ \\
\hline$\delta$-cadinene & 30.042 & 1532 & 1522 & 7.39 \\
\hline$\gamma$-cuprenene & 30.391 & 1541 & 1532 & 4.87 \\
\hline$\alpha$-cadinene & 30.573 & 1545 & 1537 & 0.51 \\
\hline \multicolumn{5}{|l|}{ Alcohols, ketones and aldehydes } \\
\hline Spathulenol & 31.613 & 1571 & 1577 & 1.90 \\
\hline Viridiflorol & 32.136 & 1584 & 1592 & 1.53 \\
\hline Thujopsan-2- $\alpha$-ol & 32.513 & 1593 & 1586 & 1.28 \\
\hline Globulol & 32.836 & 1602 & 1590 & 1.26 \\
\hline Epi-cedrol & 33.383 & 1616 & 1618 & 2.48 \\
\hline Isolongifolan-7- $\alpha$-ol & 33.778 & 1626 & 1618 & 1.32 \\
\hline Cis-cadin-4-en-7-ol & 34.230 & 1638 & 1635 & 0.65 \\
\hline Methyl Z-jasmonate & 34.620 & 1648 & 1648 & 2.66 \\
\hline Epi- $\alpha$-muurolol & 34.806 & 1653 & 1640 & 4.50 \\
\hline$\alpha$-muurolol & 34.975 & 1657 & 1644 & 1.81 \\
\hline$\alpha$-cadinol & 35.330 & 1667 & 1652 & 5.23 \\
\hline Epi- $\beta$-Bisabolol & 35.558 & 1673 & 1670 & 3.39 \\
\hline Trans-Calamenen-10-ol & 35.824 & 1679 & 1668 & 0.18 \\
\hline Z- $\gamma$-Atlantone & 36.729 & 1703 & 1694 & 2.56 \\
\hline Eremofilone & 38.198 & 1743 & 1734 & 0.66 \\
\hline \multicolumn{5}{|l|}{ Aromatic sesquiterpene } \\
\hline$\alpha$-corocalene & 34.003 & 1632 & 1622 & 0.56 \\
\hline$\alpha$-calacorene & 30.829 & 1552 & 1544 & 1.35 \\
\hline \multicolumn{5}{|l|}{ Diterpenes } \\
\hline Ent-rosa-5,15-diene & 45.150 & 1939 & 1933 & 0.27 \\
\hline Kaurene & 48.799 & 2043 & 2042 & 0.87 \\
\hline Total (identified) & & & & 81.88 \\
\hline \multicolumn{5}{|l|}{ Unidentified } \\
\hline & 25.187 & 1415 & -- & 0.56 \\
\hline & 26.569 & 1448 & -- & 0.50 \\
\hline & 28.451 & 1493 & -- & 0.36 \\
\hline & 28.761 & 1500 & -- & 4.73 \\
\hline & 29.861 & 1528 & -- & 0.56 \\
\hline & 31.047 & 1557 & -- & 0.49 \\
\hline & 31.372 & 1565 & -- & 4.23 \\
\hline & 32.255 & 1587 & -- & 1.44 \\
\hline & 32.969 & 1605 & -- & 0.53 \\
\hline & 33.262 & 1613 & -- & 1.79 \\
\hline & 34.323 & 1640 & -- & 0.22 \\
\hline & 36.285 & 1692 & -- & 2.20 \\
\hline & 38.693 & 1757 & -- & 1.09 \\
\hline Total (Unidentified) & & & & 18,7 \\
\hline
\end{tabular}

$\mathrm{TR}=$ retention time (minutes), $\mathrm{IRt}=$ retention index (Adams, 2007), $\mathrm{IRc}=$ retention index calculated, \% = percentage of component. 
The major chemical constituents in order of abundance were: $\delta$-cadinene $(7.39 \%), \beta$-sesquiphellandrene (6.67\%), $\beta$-elemene $(5.41 \%)$, sequiterpenes and $\alpha$-cadinol alcohol $(5,23 \%)$ (Figure 1). $\delta$-cadinene is among the major components of essential oils of other species of $O$. genus, such as $O$. gomezii, O. morae (Chaverri, Díaz, Cicció, 2011), O. bracteosa (Takaku, Haber, Setzer, 2007), $O$. brenesii (Chaverri, Cicció, 2005), O. valerianae and a new one called Ocotea "small leaf” (Takaku, Haber, Setzer, 2007). All the mentioned species presented predominance of sesquiterpenos in the composition of their essential oils.
1

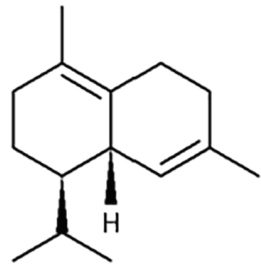

3

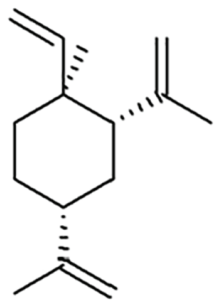

2

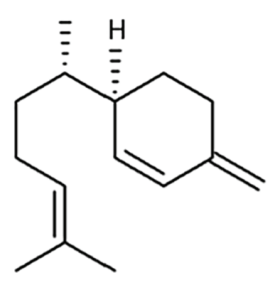

4

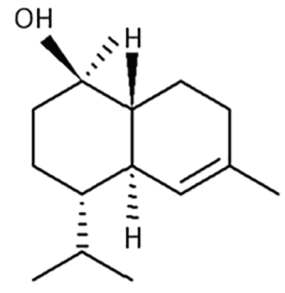

FIGURE 1 - Majority components of Ocotea bicolor essential oil. (1) $\delta$-cadinene, (2) $\beta$-sesquiphellandrene, (3) $\beta$ - elemene, (4) $\alpha$-cadinol.

Coming from the cyclization of nerolidine pyrophosphate, $\delta$-cadinene presents a cadinane skeleton, which the precursor is the farnesyl pyrophosphate (RuizReyes, Suarez, 2015). Among the activities reported in the literature for $\delta$-cadinene can be mentioned the antitumor activity (Wright et al., 2007), antimicrobial activity (Skaltsa et al., 2003) and anti-cariogenic activity (Muroi, Kubo, 1993).

The yield of $3.2 \%$ of the $O$. bicolor essential oil was considerably higher when compared to other species of the same genus: $O$. odoriferous $1.2 \%$ (Cansian et al., 2010), O. ceanothifolia $0.11 \%$, O. leucoxylon $0.13 \%$, O. minor
$0.11 \%$ (Yamaguchi, 2011), O. nigrescens, $0.23 \%$ and O. splendens, $0.35 \%$ (Alcântara, 2009). Environmental factors to which the plants species are subjected to, such as light, temperature and humidity, have significant influence on the emission of volatile compounds, altering their yield (Dudareva, Pichersky, Gershenzon, 2004).

The antioxidant activity results are described in Table II. The $O$. bicolor essential oil presented better results than rutin standard $(102.5 \%)$, deducing that this species has considerable amount of phosphomolybdenum reductive action. This assay is based on the reduction of molybdenum VI in molybdenum $\mathrm{V}$, in the presence of certain antioxidant substances, resulting in a green complex formation. Furthermore, it has the advantage of evaluating the antioxidant capacity of both lipophilic and hydrophilic components (Prieto, Pineda, Aguilar, 1999).

However, the antioxidant potential of the oil, determined based on the sequestering activity of DPPH', demonstrated a different profile. This test measures the capacity that a specific substance has in sequester the $\mathrm{DPPH} \cdot$, which is capable of accepting a hydrogen radical to become a stable diamagnetic molecule diphenylpicrylhydrazine. Thus, the simultaneous change in coloration from violet to pale yellow occurs with consequent disappearance of the absorption, can be monitored by decreasing of the absorbance. From the obtained results, the percentage of DPPH is determined for the remaining oil in the reaction medium (Alves et al., 2010; Molyneux, 2004).

The result of the antioxidant activity from this method demonstrated that concentrations above $500 \mu \mathrm{g} /$ $\mathrm{mL}$ were necessary to reduce $50 \%$ of DPPH present in the reaction medium. The discrepancy between the results obtained in both the techniques applied may be associated with the mechanisms involved in this method and the hydro/lipophilicity of the antioxidant substances present in the essential oil.

Studies with Beilschmiedia genus (LAURACEAE) demonstrated antioxidant activity in Beilschmiedia kunstleri, Beilschmiedia maingayi and Beilschmiedia penangiana, which present a predominance of sesquiterpenes in the essential oil composition. The DPPH method showed the best result for Beilschmiedia maingayi (IC $5084.7 \mu \mathrm{g} / \mathrm{mL}$ ) (Salleh et al., 2016).

TABLE II - Antioxidant activity of Ocotea bicolor essential oil obtained by phosphomolybdenum, DPPH

\begin{tabular}{|c|c|c|c|}
\hline \multirow{2}{*}{ Sample } & \multicolumn{2}{|c|}{ PHOSPHOMOLYBDENUM } & \multirow{2}{*}{$\begin{array}{c}\text { DPPH } \\
\mathrm{IC}_{50}(\mu \mathrm{g} / \mathrm{mL}) \\
\end{array}$} \\
\hline & AA in relation to rutin $(\%)$ & AA in relation to ascorbic acid (\%) & \\
\hline $\mathrm{EO}$ & $29.21 \pm 2.01$ & $102.5 \pm 7.07$ & $>500$ \\
\hline
\end{tabular}

$\mathrm{AA}=$ Antioxidant activity, $\mathrm{EO}=$ essential oil. Results are expressed as mean \pm standard deviation $(\mathrm{n}=3)$ 
However, in another study with Beilschmiedia madang also with sesquiterpenes predominance, the antioxidant activity by DPPH method was insignificant with IC50 $=263.9 \mu \mathrm{g} / \mathrm{mL}$ in leaf oil and $212.0 \mu \mathrm{g} / \mathrm{mL}$ for barley oil (Salleh, Ahmad, Yen, 2015).

O. bicolor essential oil showed MIC values $>1000$ $\mu \mathrm{g} / \mathrm{mL}$ for Gram-positive and Gram-negative bacteria tested. Sesquiterpenes as $\delta$-cadinene, $\alpha$ humulene and caryophyllene had their bactericidal activity proven (Muroi, Kubo, 1993; Skaltsa et al., 2003; Sylvestre et al., 2006; Veiga Junior, Pinto, 2002). However, when these substances are tested together, this activity may be reduced by competitive inhibition among them or enhanced because of the synergistic effect.

The brine shrimp bioassay correlates with cytotoxicity on $9 \mathrm{~Kb}$ and 9PS cells (leukemia), confirming that it is a useful tool for the preliminary determination of antitumor activity (Meyer et al., 1982; Mclaughlin, Rogers, Anderson, 1998). The O. bicolor essential oil had positive toxicity in this assay, demonstrating LC50 of $40.10(\mu \mathrm{g} / \mathrm{mL})$.

The toxic potential of essential oils from species of Lauraceae to Artemia salina is well documented in the literature. Studies with Licaria canella and Aniba canelilla showed LC50 of $5.25(\mu \mathrm{g} / \mathrm{mL})$ and 68.37 $(\mu \mathrm{g} / \mathrm{mL})$ respectively (Silva et al., 2009), O. notata, presented LC50 of $2.3737 \mu \mathrm{g} / \mathrm{mL}$ (Garret et al., 2007) and Beilschmiedia brenesii, Cinnamomum paratriplinerve and Ocotea endresiana (LC50 = 9.05, 8.07 and $6.93 \mu \mathrm{g} / \mathrm{mL}$, respectively) (Agius et al., 2007).

In addition, the $\beta$-elemene and $\alpha$-cadinol present in the essential oil as the major components showed pronounced antitumor activity in a variety of cell lines (Tao et al., 2006; Wang et al., 2005; He et al., 1997; Sylvestre et al., 2006).

The mixture of other components found in this oil, such as $\alpha$-humulene and caryophyllene are also reported in the literature as antitumor agents, which may increase the toxicity of the essential oil by synergism (Sylvestre et al., 2006; Veiga Junior, Pinto, 2002).

Although there is no accentuated bactericidal activity in the $O$. bicolor essential oil leaves, the positivity for the antioxidant activity and pronounced toxicity can be directed towards vivo studies where these characteristics can be tested.

\section{ACKNOWLEDGEMENTS}

The authors are thankful to the Commission for the Improvement of Higher Education Personnel (CAPES) from Brazil for the financial support, the taxonomist
Marcelo Leandro Brotto for help in the identification of the plant material, and Department of Chemistry of the Federal University of Paraná, Brazil, for the assistance in $\mathrm{GC} / \mathrm{MS}$ analysis.

\section{REFERENCES}

Adams, RP. Identification of essential oil components by gas chromatography / mass spectrometry. 4 ed. Carol Stream IL: Allured Publishing; 2007. 804 p.

Alcântara JM. Bioprospecção de espécies amazônicas da família Lauraceae com potencial aromático e medicinal. [dissertação]. Manaus: Universidade Federal do Amazonas; 2009.

Agius BR, Setzer MC, Stokes SL, Walker TM, Haber WA, Setzer WN. Composition and bioactivity of essential oils of Lauraceae from Monteverde, Costa Rica. Int J Essent. Oil Ther. 2007;1:167-171.

Alves CQ, David JM, David JPDL, Bahia MV, Aguiar RM. Métodos para determinação de atividade antioxidante in vitro em substratos orgânicos. Quím Nova. 2010;33(10):2202-2210.

Amarante CB, Müller AH, Póvoa MM, Dolabela MF. Estudo fitoquímico biomonitorado pelos ensaios de toxicidade frente à Artemia salina e de atividade antiplasmódica do caule de aninga (Montrichardia linifera). Acta Amaz. 2011;41(3):431-434.

Brotto ML, Cervi AC, Santos EP. O gênero Ocotea (Lauraceae) no estado do Paraná, Brasil. Rodriguésia.2013;64(3):495-525.

Bruni R, Medici A, Andreotti E, Fantin C, Muzzoli M, Dehesa M, Sacchetti G. Chemical composition and biological activities of Ishpingo essential oil, a traditional Ecuadorian spice from Ocotea quixos (Lam.) Kosterm.(Lauraceae) flower calices. Food Chem. 2004;85(3):415-421.

Cansian RL, Mossi AJ, Paroul N, Toniazzo G, Zboralski F, Prichoa, FC, Lerin LA. Atividade antioxidante e antimicrobiana de extratos de canela-sassafrás (Ocotea odorífera (Vell.) Rowher). Perspectiva. 2010;34(127):123-133.

Chao, LK, Hua KF, Hsu HY, Cheng SS, Liu JY, Chang ST. Study on the antiinflammatory activity of essential oil from leaves of Cinnamomum osmophloeum. J Agric Food Chem. 2005;53(18):7274-7278. 
Chaverri C, Cicció, JF. Essential oil of trees of the genus Ocotea (Lauraceae) in Costa Rica. I. Ocotea brenesii. Rev Biol Trop. 2005;53(3-4):431-436.

Chaverri C, Díaz, C, Cicció, JF. Chemical Analysis of Essential Oils from Ocotea gomezii WC Burger and Ocotea morae Gómez-Laur.(Lauraceae) Collected at» Reserva Biológica Alberto M. Brenes» in Costa Rica and their Cytotoxic Activity on Tumor Cell Lines. J Braz Chem Soc. 2011;22(4):741-745.

Clinical and Laboratory Standard Institute. CLSI. Methods for dilution antimicrobial susceptibility tests for bacteria that grow aerobically; approved standard. 9 edition. 2012.68 p.

Dudareva N, Pichersky E, Gershenzon J. Biochemistry of plant volatiles. Plant Physio. 2004;135(4):1893-1902.

Farmacopéia Brasileira. 5 ed. Atheneu: São Paulo, 2010.

Garrett R, Cruz RA, Guerra MS, Gattuso M, Rocha L. Atividade antibacteriana do óleo essencial de Ocotea notata guiada pelo ensaio de toxidade sobre Artemia salina Leach. BLACPMA. 2007;6(6):344-345.

He K, Zeng L, Shi G, Zhao GX, Kozlowski JF, McLaughlin JL. Bioactive compounds from Taiwania cryptomerioides. J Nat Prod. 1997;60(1):38-40.

Madriñán S. Rhodostemonodaphne (Lauraceae). New York: New York Botanical Garden, 2004. 102 p. (Flora Neotropica. Monograph, n. 92).

Mclaughlin JL, Rogers LL, Anderson JE. The use of biological assays to evaluate botanicals. Drug Inf J. 1998;32:513-524.

Mensor LL, Menezes FS, Leitão GG, Reis AS, Santos TCD, Coube CS, Leitão SG. Screening of Brazilian plant extracts for antioxidant activity by the use of DPPH free radical method. Phytother Res. 2001;15(2):127-130.

Meyer BN, Ferrigni NR, Putnam JE, Jacobsen LB, Nichols DJ, McLaughlin JL. Brine shrimp: a convenient general bioassay for active plant constituents. Planta Med. 1982;45(5):31-34.

Molyneux P. The use of the stable free radical diphenylpicrylhydrazyl (DPPH) for estimating antioxidant activity. Songklanakarin J Sci Tech. 2004;26(2):211-219.
Muroi H, Kubo I. Combination effects of antibacterial compounds in green tea flavor against Streptococcus mutans. J Agric Food Chem, 1993;41(7):1102-1105.

Nascimento JC, Lage LFO, Camargos CRD, Amaral JC, Costa LM, Sousa AN, Oliveira FQ. Determinação da atividade antioxidante pelo método DPPH e doseamento de flavonóides totais em extratos de folhas da Bauhinia variegata $\mathrm{L}$. Rev Bras Farm. 2011;92(4):327-332.

Prieto P, Pineda M, Aguilar M. Spectrophotometric quantitation of antioxidant capacity through the formation of a phosphomolybdenum complex: specific application to the determination of vitamin E. Anal Biochem. 1999;269(2):337341 .

Ruiz-Reyes E, Suarez M. Lactonas sesquiterpénicas. Diversidad estructural y sus actividades biológicas. Rev CENIC Cienc Biol. 2015;46(1):9-24.

Salleh WMNHW, Ahmad F, Khong HY, Mohamed Zulkifli R. Comparative study of the essential oils of three Beilschmiedia species and their biological activities. Int J Food Sci Technol. 2016;51(1):240-249.

Salleh WMNHW, Ahmad, F, Yen, KH. Chemical compositions and biological activities of the essential oils of Beilschmiedia madang Blume (Lauraceae). Arch Pharm Res. 2015;38(4):485493.

Santos MH, Batista BL, Duarte SM, Abreu CMP, Gouvêa CMCP. Influência do processamento e da torrefação sobre a atividade antioxidante do café (Coffea arabica). Quím Nova. 2007;30(3):604-610.

Silva JRDA, do Carmo, DF, Reis, ÉM, Machado G, Leon LL, Silva BOD, Ferreira JLP et al. Chemical and biological evaluation of essential oils with economic value from Lauraceae species. J Braz Chem Soc. 2009;20(6):1071-1076.

Silva WD, Braz-Filho R, Gottlieb OR. Bicyclooctanoid neolignans from Ocotea costulatum. Phytochemistry. 1989;28(2):661-662.

Skaltsa HD, Demetzos C, Lazari D, Sokovic, M. Essential oil analysis and antimicrobial activity of eight Stachys species from Greece. Phytochemistry. 2003;64(3):743-752. 
Sylvestre M, Pichette A, Longtin A, Nagau F, Legault J. Essential oil analysis and anticancer activity of leaf essential oil of Croton flavens L. from Guadeloupe. J Ethnopharmacol. 2006;103(1):99-102.

Takaku S, Haber WA, Setzer, WN. Leaf essential oil composition of 10 species of Ocotea (Lauraceae) from Monteverde, Costa Rica. Biochem Syst Ecol. 2007;35(8):525-532.

Tao L, Zhou L, Zheng L, Yao M. Elemene displays anti-cancer ability on laryngeal cancer cells in vitro and in vivo. Cancer Chemother Pharmacol. 2006;58(1):24-34.

Van Der Werff H, Ritcher, HG. Toward and improved classification of Lauraceae. Ann Missouri Bot Gard. 1996;83(3):409-418.

Veiga Junior VF, Pinto AC. O gênero Copaifera L. Quím Nova. 2002;5(2):273-286.
Wang G, Li X., Huang F, Zhao J, Ding H, Cunningham C, Li QQ. Antitumor effect of $\beta$-elemene in non-small-cell lung cancer cells is mediated via induction of cell cycle arrest and apoptotic cell death. Cell Mol Life Sci. 2005; 62(7):881-893.

Wright BS, Bansal A, Moriarity DM, Takaku S, Setzer WN. Cytotoxic leaf essential oils from Neotropical Lauraceae: Synergistic effects of essential oil components. Nat Prod Commun. 2007;2(12):1241-1244.

Yamaguchi KKL. Estudos biológicos dos extratos e composição química dos óleos essenciais de espécies da família Lauraceae. [dissertação]. Manaus: Universidade Federal do Amazonas; 2011.

Received for publication on $24^{\text {th }}$ May 2017 Accepted for publication on $21^{\text {st }}$ June 2017 